\title{
PENGARUH PENGGUNAAN FACEBOOK TERHADAP PERILAKU CYBERBULLYING DI KALANGAN REMAJA DESA MANTINGAN KECAMATAN TAHUNAN KABUPATEN JEPARA
}

\section{Mahfudlah Fajrie, Noor Syaidah}

Fakultas Dakwah dan Komunikasi UNISNU Jepara

Jalan Taman Siswa (Pekeng) Tahunan, Jepara, Jawa Tengah

mahfudlahfajrie@gmail.com, noorsyaidah925@gmail.com

\begin{abstract}
This research aimed the influenceof using facebook toward cyberbullying behavior. The hypothesis in this research wasthere was an influenceof using facebook toward cyberbullying behavior among village adolescentsMantingan. Subject in this research were 61 adolescents in aged range 1517 years old consist of 30 boys adolescents and 31 girls adolescents. The sampling technique used was proportional sampling. Method of collecting data consist of observation, interview, and questionnaire. The data was analyzed using aplikation IBM SPSS Statistics 25. Result of test correlation using correlation product moment between using facebook with cyberbullying behavior was 0,964 with value significant 0,000, which means there was a significant positive between using facebook toward cyberbullying behavior among village adolescents Mantingan.

Keywords: Facebook, cyberbullying, adolescent
\end{abstract}

\begin{abstract}
Abstrak
Penelitian ini bertujuan untuk mengetahui pengaruh penggunaan facebook terhadap perilaku cyberbullyingpada remaja Desa Mantingan. Hipotesis yang diajukan dalam penelitian ini adalah terdapat pengaruh penggunaan facebook terhadap perilaku cyberbullying di kalangan remaja Desa Mantingan. Subjek pada penelitian ini adalah 61 remaja dengan rentang usia 15-17 tahun yang terdiri dari 30 remaja laki-laki dan 31 remaja perempuan. Teknik sampling yang digunakan adalah proporsional sampling. Metode pengumpulan data terdiri dari observasi, wawancara dan kuesioner. Data dianalisis menggunakan aplikasi IMB SPSS Statistics 25. Hasil uji korelasi menggunakan analisis korelasi product moment antara penggunaan facebook dengan perilaku cyberbullying adalah 0,964 dengan nilai signifikansi sebesar 0,000 yang berarti terdapat pengaruh signifikan dan positif antara penggunaan facebook terhadap perilaku cyberbullying di kalangan remaja Desa Mantingan.
\end{abstract}

Kata kunci: Facebook, cyberbullying, remaja 


\section{A. PENDAHULUAN}

Informasi dan teknologi di era modern ini merupakan faktor yang sangat dominan sehingga sulit untuk dipisahkan. Berkat kemajuan dari teknologi, maka informasi dapat menyebar secara cepat dan telah mengubah tatanan kehidupan masyarakat.

Kebutuhan akan informasi untuk segala keperluan hidup manusia sangatlah tinggi. Terutama di negara maju, tidak terkecuali pula di negara berkembang, untuk mengejar ketertinggalannya negara berkembang juga mengikuti perkembangan informasi. Internet sudah menjadi suatu kebutuhan bagi semua orang, apalagi di era globalisasi ini tidak ada lagi jarak dan batas pemisah antara satu negara dengan negara lain, dengan internet komunikasi bisa dilakukan dengan semua orang di seluruh dunia.

Teknologi informasi semakin berkembang dan berpengaruh pada peradaban manusia. Jejaring sosial mulai terbentuk dan mengikutsertakan masyarakat pada pola budaya baru yang dapat mengarah pada sikap antisosial ataupun prososial. Melalui media sosial informasi dapat menyebar dengan mudah di masyarakat. Informasi dalam bentuk apapun dapat tersebar secara mudah sehingga dapat memengaruhi pola pikir hingga gaya hidup masyarakat.

Mengakses internet sudah menjadi rutinitas kebanyakan masyarakat. Berbagai jejaring sosial pun menjadi pilihan masyarakat seperti facebook, twitter, line dan instagram. Akan tetapi jejaring sosial yang paling diminati di Indonesia adalah facebook. Berdasarkan penelitian yang dilakukan oleh We Are Social pada Januari
2018, facebook menempati rating kedua setelah youtube. Tercatat $41 \%$ pengguna mediasosialdiIndonesiayangmenggunakan facebook (Pertiwi, https://tekno.kompas. $\mathrm{com} / \mathrm{read} / 2018 / 03 / 01 / 10340027 /$ risetungkap-pola-pemakaian-medsos-orangindonesia.).

Pada mulanya facebook adalah situs web jejaring sosial yang menghubungkan satu orang dengan orang lainnya yang digunakan untuk berkirim pesan hingga mengetahui akitivitas orang lain. Situs ini dikeluarkan pada tanggal 4 Februari 2004. kemudian Pendiri situs Facebook Mark Zuckerberg mulai memperluas anggotanya ke sekolah-sekolah lain di wilayah Boston dan semua sekolah yang termasuk dalam Ivy League. Facebook mulai populer pada tahun 2006 dan penggunanya saat ini sudah tersebar ke seluruh dunia (tamburaka, 2013:79).

Ada dua sisi dari penggunaan facebook yaitu apabila digunakan dengan baik maka dapat memberikan manfaat penggunanya seperti untuk mencari teman bahkan sebagai alat untuk promosi berjualan. Tetapi, apabila jejaring sosial facebook disalahgunakan sebagai alat untuk melakukan cyber bullying (intimidasi melalui dunia maya), maka akan berdampak buruk bagi penggunanya.

Perilaku cyber bullying mulai dikenal saat media cyber (media sosial) mulai digunakan. Cyberbullying adalah tindakan agresif yang dilakukan dengan menggunakan sarana elektronik oleh kelompok atau individu berulang kali serta dari waktu ke waktu terhadap korban yang tidak bisa membela dirinya (Smith, 2008:376). Tindakan tersebut mengacu 
pada insiden di mana remaja menggunakan teknologi untuk menggangu, mengancam, menghina bahkan melakukan perbuatan yang memicu pada pertengkaran dengan teman sebaya (Hinduja \& Patchin, www. cyberbullying.us).

Pelaku dari cyberbullying pada umumnya dilakukan oleh remaja. Hal ini dikarenakan remaja belum bisa mengendalikan emosinya dan dipengaruhi oleh beberapa faktor seperti sifat dendam, sakit hati, iri, cemburu, marah dan ingin terlihat hebat (Jalil, Abduljalil.web.ugm. ac.id/2015/02/12/cyberbullying/).

Berdasarkan observasi yang telah dilakukan peneliti, cyberbullying terjadi di Desa Mantingan Jepara dipicu karena adanya sikap ingin mengintimidasi yang dilakukan oleh para remaja. Intimidasi tersebut dapat berupa cacian, makian, ataupun mengunggah foto di akun Facebook mereka. Hal ini dilakukan untuk menjatuhkan serta mempermalukan korban cyberbullying. Pertanyaan penelitian yang dimunculkan adalah Bagaimana pengaruh penggunaan facebook terhadap perilaku cyberbullying di kalangan remaja di Desa Mantingan Kecamatan Tahunan Kabupaten Jepara?

\section{B. METODE PENELITIAN}

Penulis menggunakan jenis penelitian metode kuantitatif. Waktu penelitian dilakukan kurang lebih 6 bulan terhitung mulai dari bulan Juli 2018 sampai Maret 2019 untuk mengamati dan mengumpulkan data yang ada di lapangan. Tempat penelitian dilakukan di Desa Mantingan, Kecamatan Tahunan yang terdiri dari 29 RT (Rukun Tetangga) dan 8 RW (Rukun Warga). Populasi dalam penelitian ini adalah remaja dengan rentang usia 15-17 tahun yang bertempat tinggal di Desa Mantingan Kecamatan Tahunan Kabupaten Jepara. Adapun jumlah remaja dalam rentang usia tersebut di Desa Mantingan berjumlah 610 orang dengan jumlah remaja laki-laki sebanyak 293 orang dan jumlah remaja perempuan 308 orang.

Teknik pengumpulan data dalam penelitian ini menggunakan beberapa metode yaitu observasi, wawancara dan kuisioner. Adapun responden yang akan diberikan kuesioner adalah para remaja dengan rentang umur 15-17 tahun yang tinggal di Desa Mantingan serta aktif menggunakan facebook.

Untuk mengetahui adanya pengaruh dua variabel yaitu antara variabel independen (penggunaan facebook) terhadap variabel dependen (perilaku cyberbullying) pada remaja di Desa Mantingan, maka analisis yang digunakan adalah dengan menggunakan teknik korelasi product moment untuk mencari koefisisen korelasi antara variabel independen $(X)$ serta variabel dependen $(Y)$ (Bungin, 2011:205).

Adapun dalam penelitian ini dianalisis dengan menggunakan aplikasi IBM SPSS Statistics 25 dengan rumus sebagai berikut (Bungin, 2011:207) :

$$
r=\frac{n\left(\sum X Y\right)-\sum X \sum Y}{\left.\sqrt{\left[n \sum X^{2}-\left(\sum X\right)^{2}\right]}\right]\left[n \sum Y^{2}-\left(\sum Y\right)^{2}\right]}
$$

Pada penelitian ini analisis korelasi product moment digunakan untuk menemukan variabel independen 
(penggunaan facebook) dengan variabel dependen (perilaku cyberbullying) mengenai ada tidaknya hubungan diantara keduanya.

\section{HASIL DAN PEMBAHASAN}

\section{Deskripsi Data Hasil Penelitian}

Di era komunikasi dan informasi seperti sekarang ini, manusia harus mampu menguasai teknologi komunikasi dan informasi. Dengan menguasai teknologi komunikasi dan informasi, maka seseorang dapat lebih mudah untuk mendapatkan informasi yang lebih cepat dan akurat, salah satunya dengan menggunakan internet.

Internet menyajikan kemudahan dalam mendapatkan akses informasi yang tidak terbatas oleh ruang dan waktu. Berdasarkan penelitian yang dilakukan oleh We Are Sosial pada Januari 2018, salah satu situs yang digunakan oleh $41 \%$ penduduk di Indonesia adalah facebook (Pertiwi, https://tekno.kompas.com/ $\mathrm{read} / 2018 / 03 / 01 / 10340027 /$ riset-ungkappola-pemakaian-medsos-orang-indonesia.).

Oleh karena itu, peneliti tertarik untuk meneliti pengaruh dari penggunaan facebook yang dapat menyebabkan terjadinya tindakan perundungan. Peneliti meneliti pengaruh penggunaan facebook terhadap perilaku cyberbullying di kalangan remaja Desa Mantingan.

Dengan menggunakan teknik proportional sampling, sampel data diambil dengan memperhatikan rentang umur antara 15-17 tahun. Adapun sampel penelitian diambil 10\% dari jumlah populasi sesuai dengan pendapat dari Arikunto, sehingga dari populasi remaja dengan rentang umur 15-17 tahun sebanyak 610 orang, maka sample pada penelitian ini berjumlah 61 responden. Kuesioner diberikan kepada responden untuk mengukur dan memperoleh gambaran dari sampel yang telah ditentukan.

Pada penelitian ini analisis product moment digunakan untuk menghitung kuesioner yang telah dibagikan kepada responden berdasarkan alternatif jawaban yang mengarah pada penggunaan facebook terhadap terjadinya tindakan cyberbullying di kalangan remaja Desa Mantingan.

1. Data penelitian

Berdasarkan kuesioner yang sudah peneliti sebar, maka diperoleh data sebagai berikut:

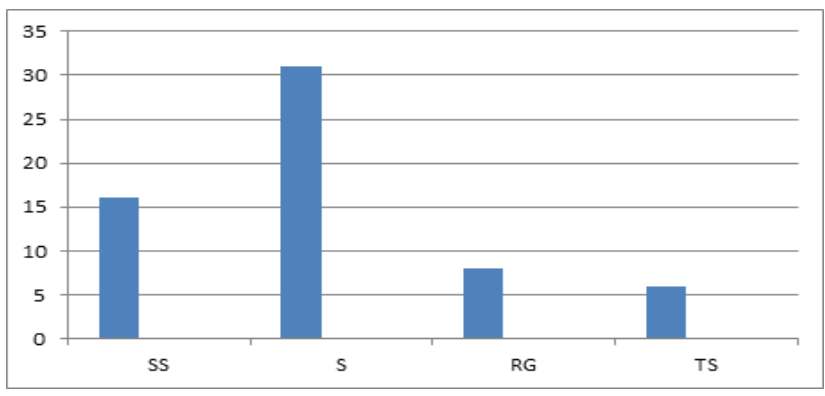

Gambar 1.

Diagram Aktif Pengguna Facebook

Berdasarkan data diagram di atas dapat dijelaskan bawah responden yang menjawab sangat setuju terhadap pernyataan aktif mengggunakan facebook adalah sebanyak 16 orang, responden yang menjawab setuju 31 orang, ragu-ragu 8 orang, dan tidak setuju 6 orang. 


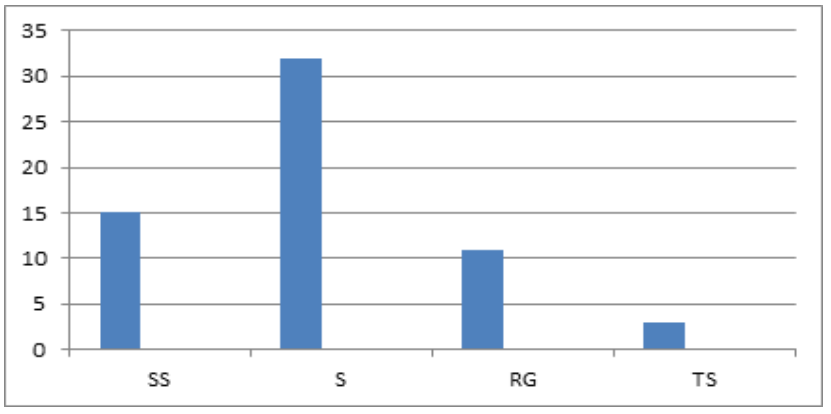

Gambar 2.

Diagram Mendapatkan Informasi Up To Date

Berdasarkan data diagram di atas responden yang menjawab sangat setuju menggunakan facebook untuk mendapatkan informasi yang up to date adalah 15 orang, jawaban setuju 32 orang, ragu-ragu 11, dan tidak setuju 2 orang.

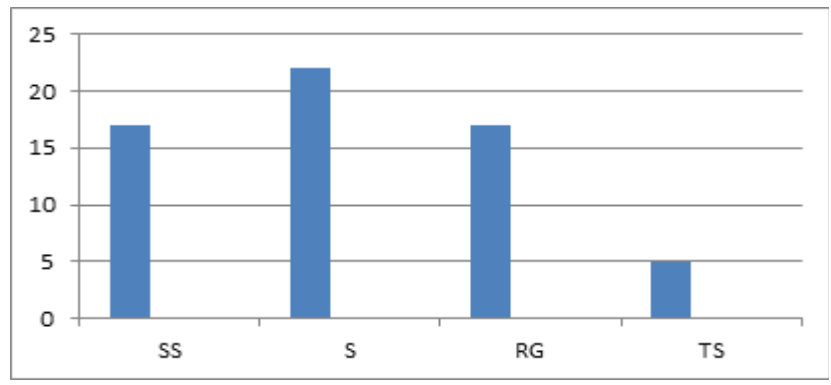

Gambar 3.

Diagram Menggunakan Facebook untuk Mendapat Fitur Menarik

Berdasarkan data diagram tersebut dapat dipaparkan bahwa responden yang menjawab sangat setuju untuk menggunakan facebook agar mendapat fitur menarik ada 17 orang, yang jawaban setuju 22 orang, ragu-ragu 17, dan tidak setuju 5 orang.

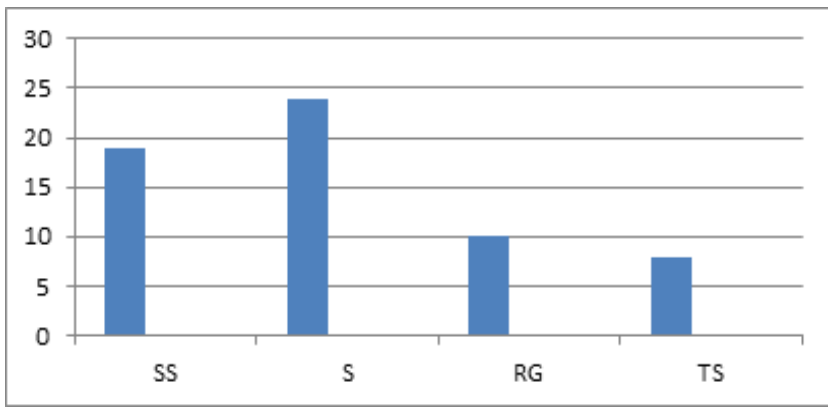

Gambar 4.

Diagram Mengirimkan Informasi Melalui Status

Berdasarkan data diagram di atas reponden yang menjawab sangat setuju untuk mengirimkan informasi melalui status di facebook ada 19 orang, responden yang menjawab setuju 24 orang, ragu-ragu 10 orang, dan tidak setuju 8 orang.

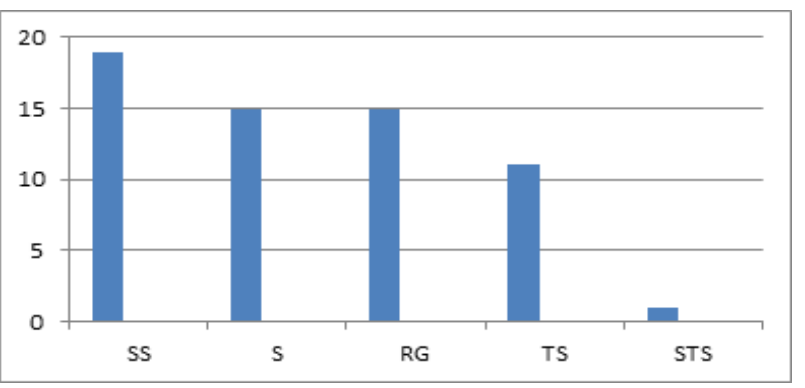

Gambar 5.

Diagram Mengirimkan Informasi Melalui Pesan (Inbox)

Berdasarkan data diagram tersebut responden yang menjawab sangat setuju untuk pernyataan mengirimkan informasi lewat status adalah 19 orang, jawaban setuju 15 orang, ragu-ragu 15 orang, tidak setuju 11 dan sangat tidak setuju 1 orang. 


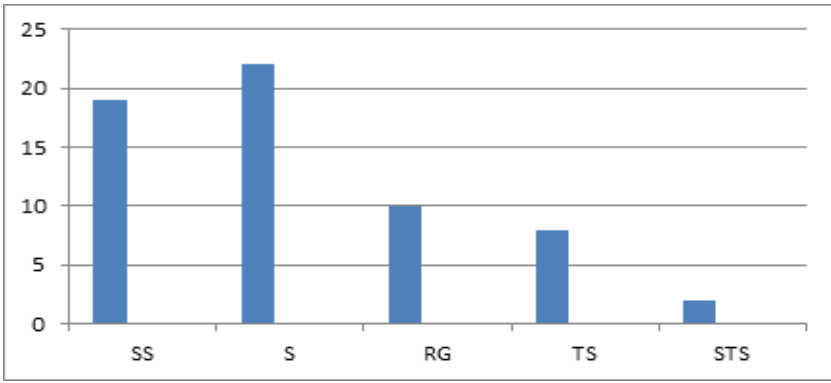

Gambar 6.

Diagram Menggunakan Facebook untuk

\section{Chatting}

Berdasarkan data diagram di atas responden yang menjawab sangat setuju menggunakan facebook untuk chatting adalah 19 orang, yang jawaban setuju 22 orang, ragu-ragu 10 orang, tidak setuju 8 dan sangat tidak setuju 2 orang.

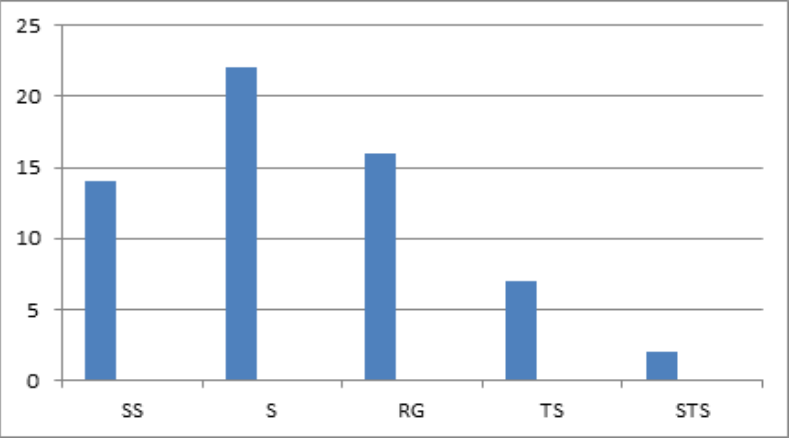

Gambar 7.

Diagram Membuat Status Saat Menggunakan Facebook

Berdasarkan data diagram tersebut dapat dipaparkan bahwa responden yang menjawab sangat setuju untuk pernyataan membuat status saat menggunakan facebook adalah 14 orang, yang menjawab setuju 22 orang, ragu-ragu 16 orang, tidak setuju 7 orang, dan sangat tidak setuju 2 orang.

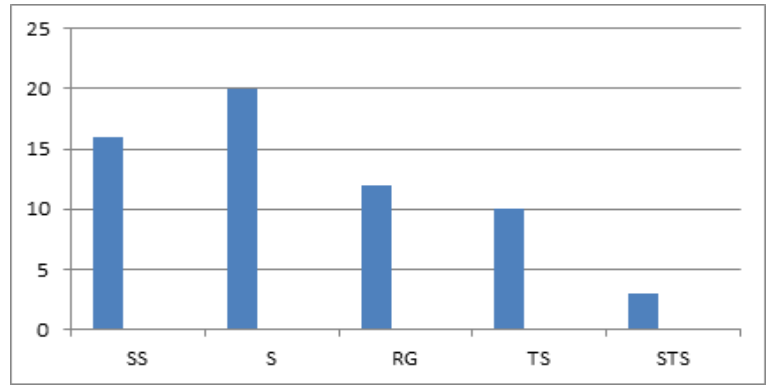

Gambar 8.

Diagram Melihat Status Orang Lain di Facebook

Berdasarkan data diagram di atas responden yang menjawab sangat setuju untuk pernyataan melihat status orang lain saat menggunakan facebook adalah 16 orang, responden yang menjawab setuju 20 orang, 12 jawaban ragu-ragu, tidak setuju 10 orang dan sangat tidak setuju 3 orang.

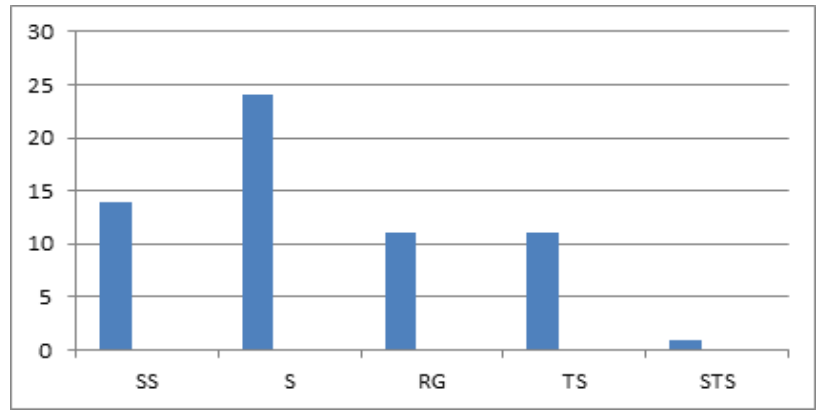

Gambar 9.

Diagram Membeli Produk yang dijual di

Facebook

Berdasarkan data diagram tersebut responden yang menjawab sangat setuju untuk membeli produk yang ditawarkan di facebook ada 14 orang, responden yang menjawab setuju 24 orang, ragu-ragu 11, tidak setuju 11, dan sangat tidak setuju 1 orang. 


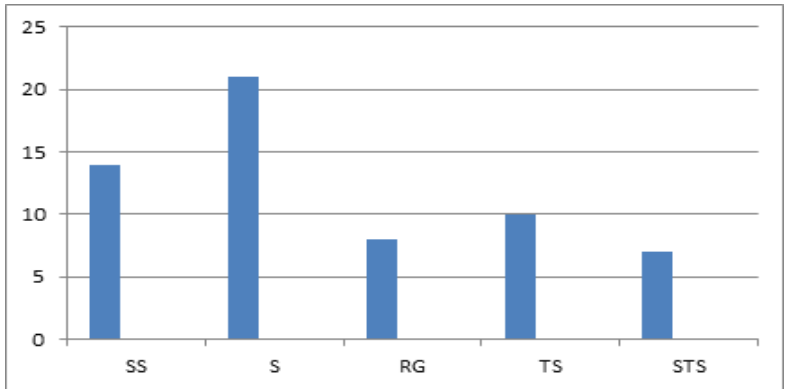

Gambar 10.

Diagram Menjual Produk di Facebook

Berdasarkan data diagram tersebut reponden yang menjawab sangat setuju untuk menjual produk secara online di facebook adalah 14 orang, responden yang menjawab setuju 21 orang, ragu-ragu 8 orang, tidak setuju 10 orang, dan sangat tidak setuju 7 orang.

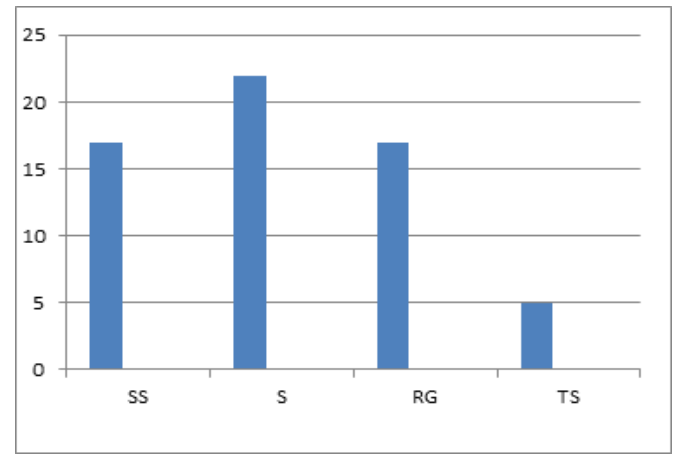

Gambar 11.

Diagram Sedikit Memiliki Rasa Empati

$$
\text { Pada Orang Lain }
$$

Berdasarkan data diagram tersebut responden yang menjawab sangat setuju pada pernyataan sedikit memiliki rasa empati pada orang lain adalah 17 orang, responden yang menjawab setuju 22 orang, ragu-ragu 17 orang, tidak setuju 5 orang.

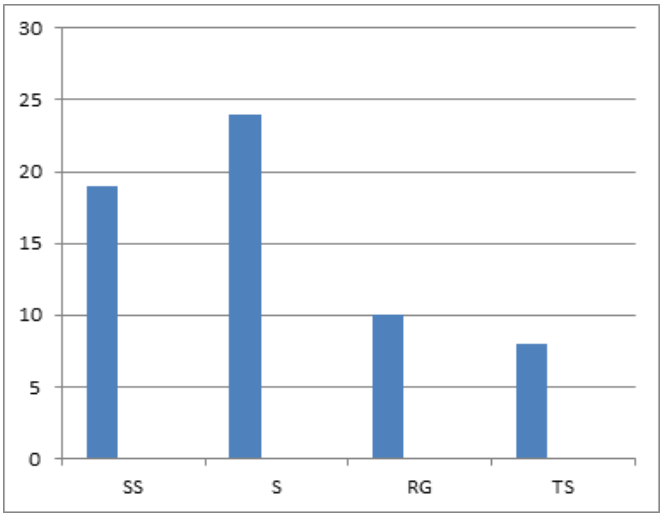

Gambar 12.

Diagram Cenderung Bersikap Keras

Berdasarkan data diagram di atas responden yang menjawab sangat setuju untuk pernyataan cenderung bersikap keras adalah 19 orang, respoden yang menjawab setuju 24 orang, ragu-ragu 10 orang, dan tidak setuju 8 orang.

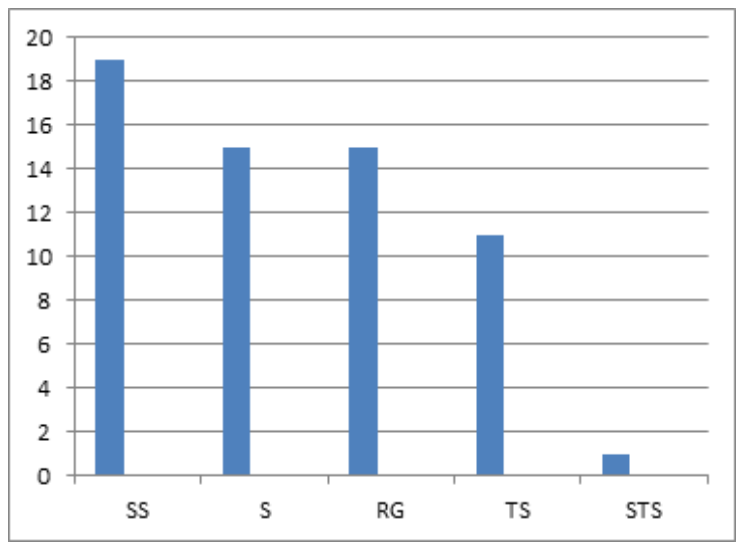

Gambar 13.

Diagram Menyukai Sensasi dan Pengalaman Baru

Berdasarkan data diagram di atas responden yang menjawab sangat setuju adalah 19 orang, responden yang menjawab setuju 15 orang, ragu-ragu 15 orang, tidak setuju 11 orang dan sangat tidak setuju 1 orang. 


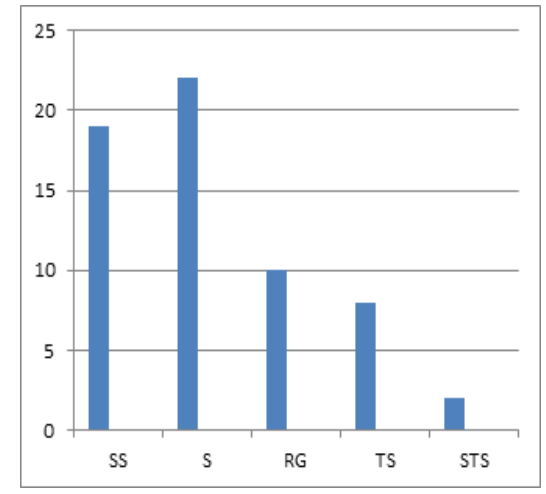

Gambar 14.

Diagram Ingin Mendapatkan Hiburan

Berdasarkan data diagram tersebut responden yang menjawab sangat setuju untuk pernyataan ingin mendapatkan hiburan adalah 19 orang, responden yang menjawab setuju 22 orang, ragu-ragu 10 orang, tidak setuju 8 orang dan sangat tidak setuju 2 orang.

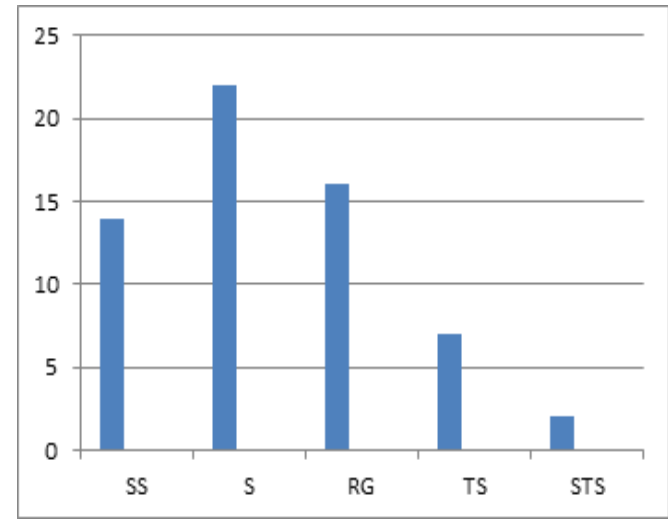

Gambar 15.

Diagram Takut Berhadapan dengan Korban yang Dibuli

Berdasarkan data diagram tersebut responden yang menjawab sangat setuju pada pernyataan takut berhadapan dengan korban yang dibulinya adalah 14 orang, reponden yang menjawab setuju 22 orang, ragu-ragu 16 orang, tidak setuju 7 orang dan sangat tidak setuju 2 orang.

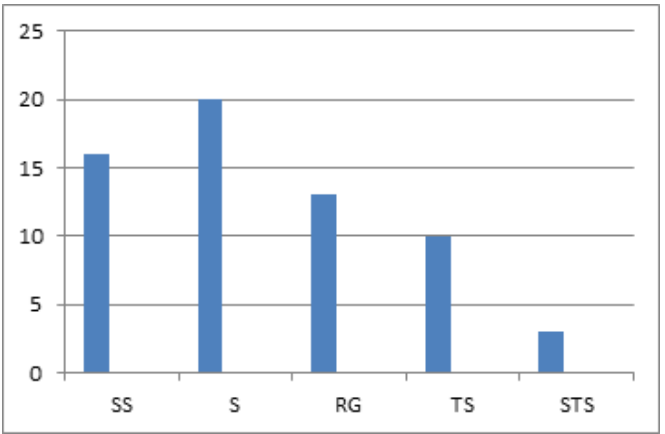

Gambar 16.

Diagram Menggunakan Akun Facebook

Palsu

Berdasarkan data diagram tersebut responden yang menjawab sangat setuju adalah 16 orang, responden yang menjawab setuju 20 orang, ragu-ragu 12 orang, tidak setuju 10 orang dan sangat tidak setuju 3 orang.

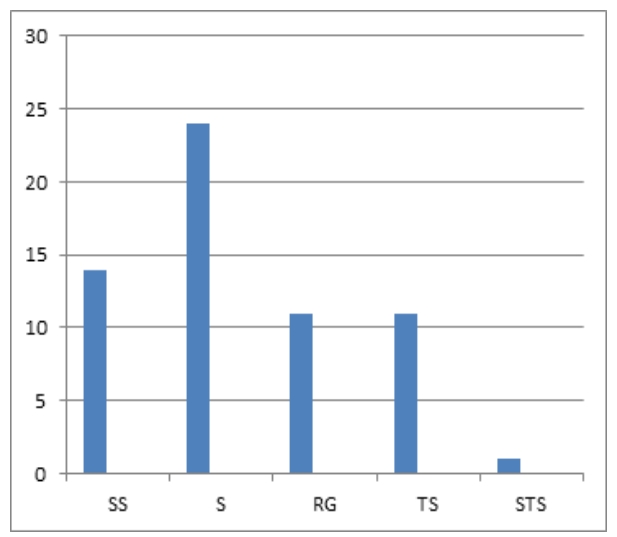

Gambar 17.

Diagram Merespon Komentar Orang di Facebook

Berdasarkan data diagram tersebut responden yang menjawab sangat setuju untuk pernyataan merespon komentar orang di facebook adalah 14 orang, responden yang menjawab setuju 24 orang, ragu-ragu 11 orang, tidak setuju 11 orang, dan sangat tidak setuju 1 orang. 
2. Distribusi Frekuensi

Distribusi frekuensi digunakan untuk mengetahui apakah pertanyaan dalam kuesioner sudah terdistribusi kepada semua responden atau tidak. Adapun untuk mengetahui nilai dari distribusi frekuensi, maka dapat memperhatikan tabel distribusi frekuensi dari kolom total. Apabila nilai dari kolom total Percent, Valid Percent dan Cummulative Percent pada tabel distribusi frekuensi berjumlah 100, maka dapat dikatakan bahwa data sudah terdistrubusi kepada seluruh responden.

Dari distribusi frekuensi pada tabel dapat diilustrasikan dengan histogram. Pada gambar histogram akan disajikan nilai frekuensi total pada distribusi frekuensi..

Adapun distribusi frekuensi dari variabel penggunaan facebook dapat dilihat pada tabel berikut ini:

Tabel 1.

Distribusi Frekuensi Penggunaan Facebook

\begin{tabular}{|c|c|c|c|c|c|}
\hline \multicolumn{6}{|c|}{ Distribusi Frekuensi Penggunaan Facebook } \\
\hline & & Frequency & Percent & $\begin{array}{c}\text { Valid } \\
\text { Percent }\end{array}$ & $\begin{array}{c}\text { Cumulative } \\
\text { Percent }\end{array}$ \\
\hline \multirow{16}{*}{ Valid } & 20 & 2 & 3,3 & 3,3 & 3,3 \\
\hline & 24 & 1 & 1,6 & 1,6 & 4,9 \\
\hline & 29 & 1 & 1,6 & 1,6 & 6,6 \\
\hline & 30 & 5 & 8,2 & 8,2 & 14,8 \\
\hline & 32 & 3 & 4,9 & 4,9 & 19,7 \\
\hline & 33 & 1 & 1,6 & 1,6 & 21,3 \\
\hline & 34 & 2 & 3,3 & 3,3 & 24,6 \\
\hline & 35 & 5 & 8,2 & 8,2 & 32,8 \\
\hline & 36 & 3 & 4,9 & 4,9 & 37,7 \\
\hline & 37 & 9 & 14,8 & 14,8 & 52,5 \\
\hline & 38 & 7 & 11,5 & 11,5 & 63,9 \\
\hline & 39 & 3 & 4,9 & 4,9 & 68,9 \\
\hline & 40 & 2 & 3,3 & 3,3 & 72,1 \\
\hline & 41 & 2 & 3,3 & 3,3 & 75,4 \\
\hline & 42 & 3 & 4,9 & 4,9 & 80,3 \\
\hline & 43 & 5 & 8,2 & 8,2 & 88,5 \\
\hline
\end{tabular}

\begin{tabular}{|c|c|c|c|c|}
\hline 44 & 1 & 1,6 & 1,6 & 90,2 \\
\hline 48 & 3 & 4,9 & 4,9 & 95,1 \\
\hline 50 & 3 & 4,9 & 4,9 & 100,0 \\
\hline Total & 61 & 100,0 & 100,0 & \\
\hline
\end{tabular}

Berdasarkan data tersebut maka dapat diartikan bahwa variabel penggunaan facebook memiliki nilai frekuensi total berjumlah 61. Adapun nilai pada kolom total Percent, Valid Percent dan Cummulative Percent menunjukkan nilai 100,0 maka dapat dikatakan bahwa data valid dengan nilai $100 \%$.

Adapununtuklebihjelasnya mengenai distribusi frekuensi dari penggunaan facebook, maka dapat disajikan dalam bentuk histogram sebagai berikut:

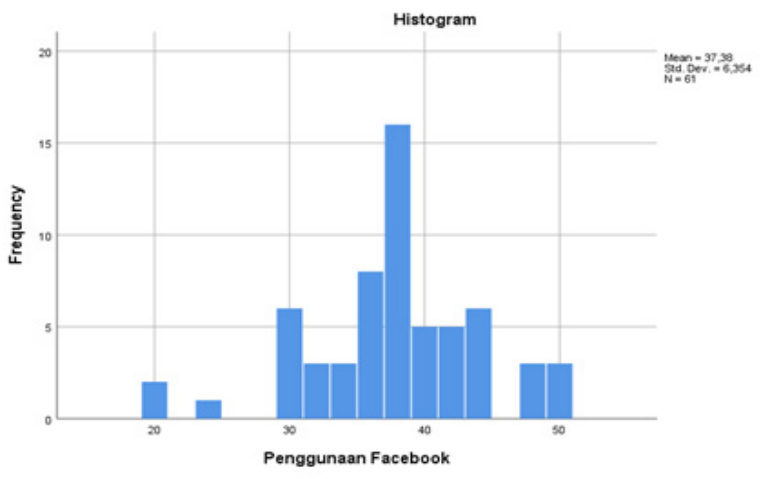

Gambar 18.

Histogram Penggunaan Facebook

Berdasarkan gambar histogram di atas, maka dapat disimpulkan bahwa variabel penggunaan facebook memiliki nilai total 61. Nilai tersebut sama dengan nilai total dari tabel distribusi frekuensi penggunaan facebook sehingga dapat dikatakan bahwa data sudah valid.

Adapun distribusi frekuensi dari variabel perilaku cyberbullying dapat dilihat pada tabel berikut: 
Tabel 2.

Distribusi Frekuensi Perilaku Cyberbullying

\begin{tabular}{|c|c|c|c|c|c|}
\hline \multicolumn{6}{|c|}{ Distribusi Frekuensi Perilaku Cyberbullying } \\
\hline & & Frequency & Percent & $\begin{array}{l}\text { Valid } \\
\text { Percent }\end{array}$ & $\begin{array}{c}\text { Cumulative } \\
\text { Percent }\end{array}$ \\
\hline \multirow{26}{*}{ Valid } & 24 & 1 & 1,6 & 1,6 & 1,6 \\
\hline & 25 & 1 & 1,6 & 1,6 & 3,3 \\
\hline & 27 & 1 & 1,6 & 1,6 & 4,9 \\
\hline & 28 & 1 & 1,6 & 1,6 & 6,6 \\
\hline & 29 & 1 & 1,6 & 1,6 & 8,2 \\
\hline & 30 & 1 & 1,6 & 1,6 & 9,8 \\
\hline & 32 & 4 & 6,6 & 6,6 & 16,4 \\
\hline & 33 & 2 & 3,3 & 3,3 & 19,7 \\
\hline & 34 & 6 & 9,8 & 9,8 & 29,5 \\
\hline & 35 & 4 & 6,6 & 6,6 & 36,1 \\
\hline & 36 & 5 & 8,2 & 8,2 & 44,3 \\
\hline & 37 & 5 & 8,2 & 8,2 & 52,5 \\
\hline & 38 & 6 & 9,8 & 9,8 & 62,3 \\
\hline & 39 & 5 & 8,2 & 8,2 & 70,5 \\
\hline & 40 & 4 & 6,6 & 6,6 & 77,0 \\
\hline & 41 & 1 & 1,6 & 1,6 & 78,7 \\
\hline & 43 & 2 & 3,3 & 3,3 & 82,0 \\
\hline & 44 & 1 & 1,6 & 1,6 & 83,6 \\
\hline & 45 & 4 & 6,6 & 6,6 & 90,2 \\
\hline & 46 & 1 & 1,6 & 1,6 & 91,8 \\
\hline & 47 & 1 & 1,6 & 1,6 & 93,4 \\
\hline & 48 & 1 & 1,6 & 1,6 & 95,1 \\
\hline & 51 & 1 & 1,6 & 1,6 & 96,7 \\
\hline & 53 & 1 & 1,6 & 1,6 & 98,4 \\
\hline & 59 & 1 & 1,6 & 1,6 & 100,0 \\
\hline & Total & 61 & 100,0 & 100,0 & \\
\hline
\end{tabular}

Berdasarkan data tersebut maka dapat diartikan bahwa variabel perilaku cyberbullying memiliki nilai frekuensitotal 61. Adapun nilai pada kolom total Percent, Valid Percent dan Cummulative Percent menunjukkan rnilai 100,0 maka dapat dikatakan bahwa data valid dengan nilai $100 \%$.

Adapun untuk lebih jelasnya mengenai distribusi frekuensi dari perilaku cyberbullying, maka dapat disajikan dalam bentuk histogram.
Berikut ini adalah histogram dari distribusi frekuensi perilaku cyberbullying sebagai berikut:

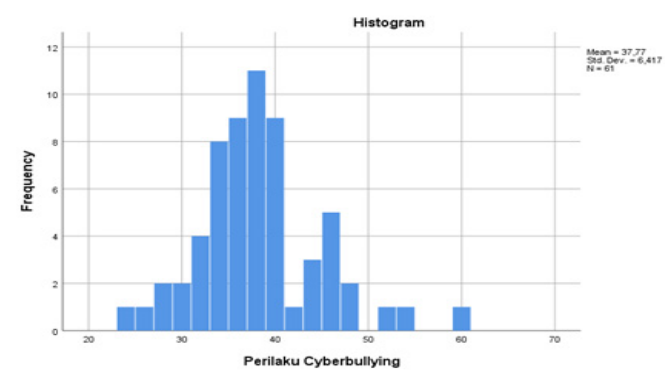

Gambar 19.

Histogram Perilaku Cyberbullying

Berdasarkan gambar histogram di atas, maka dapat disimpulkan bahwa variabel perilaku cyberbullying memiliki nilai total 61. Nilai tersebut sama dengan nilai total dari tabel distribusi frekuensi perilaku cyberbullying sehingga dapat dikatakan bahwa data sudah valid.

3. Uji Reliabilitas

Uji reliabilitas digunakan untuk mengetahui tingkat konsistensi suatu angket yang digunakan oleh peneliti. Uji reliabilitas dalam hal ini mengacu pada nilai Cronbach's Alpha If Item Deleted dalam tabel hasil uji reliabilitas.

Dasar pengambilan keputusan dalam uji reliabilitas adalah jika nilai cronbach's Alpha >0,60 maka kuesioner dinyatakan reliabel atau konsisten. Akan tetapi, apabila cronbach's Alpha<0,60, maka kuesioner dinyatakan tidak reliabel.

Berikut ini adalah tabel uji reliabilitas variabel X (Facebook): 
Tabel 3 .

Hasil Uji Reliabilitas Facebook

\begin{tabular}{|l|r|}
\hline \multicolumn{2}{|c|}{ Reliability Statistics } \\
\hline $\begin{array}{l}\text { Cronbach's } \\
\text { Alpha }\end{array}$ & N of Items \\
\hline & 107 \\
\hline
\end{tabular}

\begin{tabular}{|l|r|r|r|r|}
\hline \multicolumn{7}{|c|}{ Item-Total Statistics } \\
\hline & $\begin{array}{c}\text { Scale } \\
\text { Mean } \\
\text { if Item } \\
\text { Deleted }\end{array}$ & $\begin{array}{c}\text { Scale } \\
\text { Variance } \\
\text { if Item } \\
\text { Deleted }\end{array}$ & $\begin{array}{c}\text { Corrected } \\
\text { Item-Total } \\
\text { Correlation }\end{array}$ & $\begin{array}{c}\text { Cronbach's } \\
\text { Alpha } \\
\text { if Item } \\
\text { Deleted }\end{array}$ \\
\hline Item_1 & 33,44 & 34,051 &, 531 &, 775 \\
\hline Item_2 & 33,41 & 34,079 &, 610 &, 769 \\
\hline Item_3 & 33,54 & 34,386 &, 467 &, 780 \\
\hline Item_4 & 33,49 & 35,654 &, 311 &, 797 \\
\hline Item_5 & 33,72 & 32,971 &, 459 &, 781 \\
\hline Item_6 & 33,59 & 32,846 &, 484 &, 778 \\
\hline Item_7 & 33,74 & 31,930 &, 607 &, 763 \\
\hline Item_8 & 33,79 & 32,470 &, 479 &, 779 \\
\hline Item_9 & 33,74 & 35,063 &, 324 &, 797 \\
\hline item_10 & 33,93 & 30,929 &, 516 &, 775 \\
\hline
\end{tabular}

Berdasarkan tabel di atas, kolom untuk Cronbach's Alpha If Item Deleted untuk ke-10 itemsoal adalah $>0,60$. Maka dapat disimpulkan bahwa ke-10 item pertanyaan kuesioner reliabel.

Adapun tabel uji reliabilitas variabel $\mathrm{Y}($ Cyberullying $)$ adalah sebagai berikut:

Tabel 4.

Hasil Uji Reliabilitas Cyberbullying

\begin{tabular}{|l|r|}
\hline \multicolumn{2}{|c|}{ Reliability Statistics } \\
\hline $\begin{array}{l}\text { Cronbach's } \\
\text { Alpha }\end{array}$ & N of Items \\
\hline, 701 & 7 \\
\hline
\end{tabular}

\begin{tabular}{|l|l|l|l|l|}
\hline \multicolumn{5}{|c|}{ Item-Total Statistics } \\
\hline & $\begin{array}{l}\text { Scale } \\
\text { Mean } \\
\text { if Item } \\
\text { Deleted }\end{array}$ & $\begin{array}{l}\text { Scale } \\
\text { Variance } \\
\text { if Item } \\
\text { Deleted }\end{array}$ & $\begin{array}{l}\text { Corrected } \\
\text { Item-Total } \\
\text { Correlation }\end{array}$ & $\begin{array}{l}\text { Cronbach's } \\
\text { Alpha } \\
\text { if Item } \\
\text { Deleted }\end{array}$ \\
\hline Item_1 & 22,20 & 16,261 &, 447 &, 660 \\
\hline Item_2 & 22,15 & 17,495 &, 239 &, 707 \\
\hline Item_3 & 22,38 & 15,205 &, 441 &, 659 \\
\hline Item_4 & 22,25 & 15,255 &, 451 &, 656 \\
\hline
\end{tabular}

\begin{tabular}{|l|r|r|r|r|}
\hline Item_5 & 22,39 & 14,843 &, 551 &, 630 \\
\hline Item_6 & 22,44 & 14,817 &, 467 &, 651 \\
\hline Item_7 & 22,39 & 16,809 &, 285 &, 699 \\
\hline
\end{tabular}

Berdasarkan tabel di atas, kolom untuk Cronbach's Alpha If Item Deleted untuk ke-7 item soal adalah > 0,60. Maka dapat disimpulkan bahwa ke-7 item pertanyaan kuesioner reliabel.

\section{Uji Normalitas}

Uji normalitas dilakukan untuk mengecek data penelitian berasal dari populasiyang sebenarnya normal atau tidak. Adapun uji normalitas pada penelitian ini adalah menggunakan grafik normal P-Plot Of Regression Standardized Residual dan grafik histogram dengan menggunakan program IBM SPSS Statistics 25.

Dasar pengambilan keputusan dari uji normalitas untuk pengujian menggunakan normal P-Plot Of Regression Standardized Residual dapat dinyatakan normal apabila data yang menyebar disekitar garis diagonal dan data tidak berdistribusi normal apabila data menyebar jauh dari arah garis.

Adapun untuk pengujian menggunakan grafik histogram, data dikatakan normal apabila garis mengikuti arah grafik histogram. Sedangkan data dikatakan tidak berdistribusi normal apabila data tidak mengikuti grafik histogram.

Berikut ini adalah gambar hasil uji normalitas: 


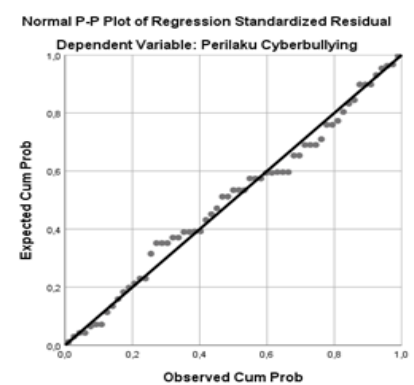

Gambar 20.

Hasil Uji Normalitas

Berdasarkan gambar grafik normal P-Plot Of Regression Standardized Residual tersebut dapat disimpulkan bahwa titiktitik pada gambar tersebut mengikuti dan mendekati garis diagonalnya sehingga dapat dikatakan bahwa data yang diteliti berdistribusi normal.

Adapun uji linearitas dapat disajikan dalam bentuk histogram sebagai berikut:

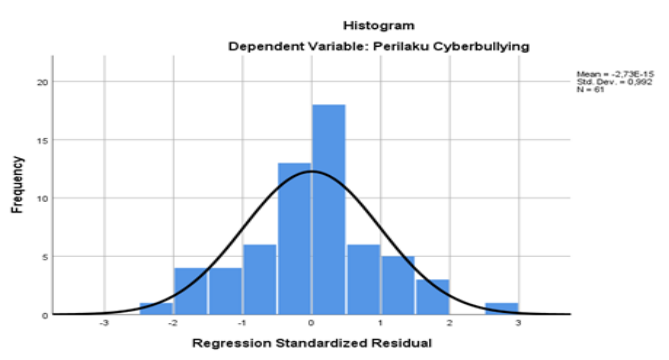

Gambar 21.

Histogram Uji Normalitas

Hasil uji normalitas pada histogram di atas menunjukkan bahwa garis kurva normal dan mengikuti arah grafik histogram. Maka dapat dikatakan bahwa data yang diteliti berdistribusi normal.

\section{Uji Linearitas}

Uji linearitas digunakan untuk mengetahui hubungan antarvariabel yang hendak dianalisis mengikuti garis lurus atau tidak. Ada dua pengambilan keputusan untuk menguji linearitas. Adapun yang pertama dengan melihat angka signifikan pada tabel Deviation From Linearity. Dua variabel bersifat linear apabila nilai Deviation From Linearity signifikannya>0,05 dan sebaliknya jika nilai Deviation From Linearity signifikannya $<0,05$ maka dua variabel dikatakan tidak bersifat linear.Yang kedua adalah dengan mencari $\mathrm{F}$ hitung dan $\mathrm{F}$ tabel. Apabila nilai $\mathrm{F}$ hitung $<\mathrm{F}$ tabel, maka dua variabel memiliki hubungan yang signifikan. Adapun sebaliknya jika nilai $\mathrm{F}$ hitung $>\mathrm{F}$ tabel, maka dua variabel tidak memiliki hubungan yang signifikan.

Berikut ini adalah tabel hasil uji linearitas:

Tabel 5.

Hasil Uji Linearitas

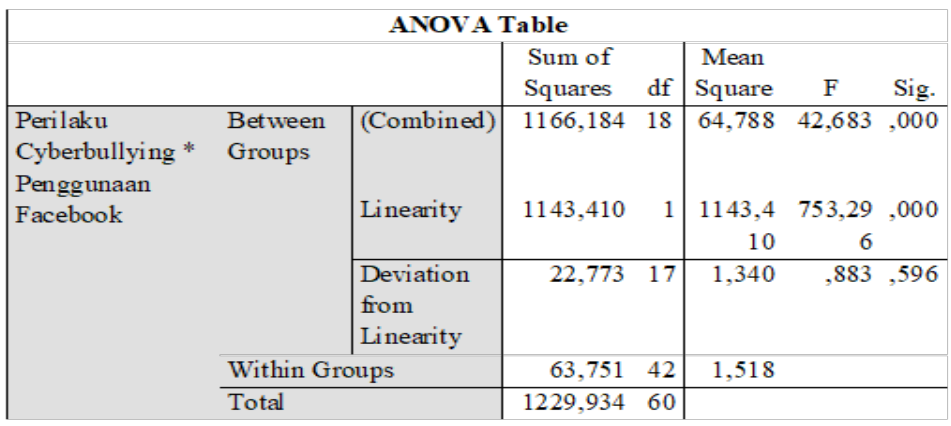

Berdasarkan tabel data hasil uji linearitas di atas, nilai Deviation From Linearty kolom sig adalah sebesar 0,596. Hal ini berarti bahwa nilai signifikansi pada uji linearitas ini $>0,05$. Jadi, sesuai dengan pengambilan keputusan pada uji linearitas maka dapat disimpulkan bahwa terdapat hubungan linear antara variabel penggunaan facebook dengan variabel perilaku cyberbullying. 
Berdasarkan data tabel di atas sudah diketahui nilai $\mathrm{F}$ hitung $=0,883$. Adapun untuk mencari $\mathrm{F}$ tabel maka dapat menggunakan rumus sebagai berikut:

Rumus F tabel

$$
\begin{aligned}
& \text { df1 }=k-1 \\
& d f 2=n-k
\end{aligned}
$$

\section{Keterangan}

$\mathrm{k}=$ jumlah variabel bebas $(\mathrm{X})$ dan variabel terikat $(\mathrm{Y})$

$\mathrm{n}=$ Jumlah responden

Diketahui

$\mathrm{k}=2$

$\mathrm{n}=61$

$\mathrm{df} 1=2-1=1$

$\mathrm{df} 2=61-2=59$

Hasil dari perhitungan tersebut didapatkan angka 1 dan 59. Angka tersebut dapat dijadikan acuan untuk mengetahui nilai dari $\mathrm{F}$ tabel.

Adapun untuk mengetahui nilai dari F table, maka dapat melihat gambar F table

\begin{tabular}{|c|c|c|c|c|c|c|c|c|c|c|c|}
\hline \multirow{3}{*}{$\begin{array}{l}\text { Ik } \\
\text { iut }\end{array}$} & \multicolumn{11}{|c|}{ Titik Persentase Distribusi F untuk Probabilita $=0,05$} \\
\hline & \multicolumn{11}{|c|}{ df untuk pembilang (N1) } \\
\hline & 1 & 2 & 3 & 4 & 5 & 6 & 7 & 8 & 9 & 10 & 11 \\
\hline 46 & 4.05 & 3.20 & 2.81 & 2.57 & 2.42 & 2.30 & 2.22 & 2.15 & 2.09 & 2.04 & 2.00 \\
\hline 47 & 4.05 & 3.20 & 2.80 & 2.57 & 2.41 & 2.30 & 2.21 & 2.14 & 2.09 & 2.04 & 2.00 \\
\hline 48 & 4.04 & 3.19 & 2.80 & 2.57 & 2.41 & 2.29 & 2.21 & 2.14 & 2.08 & 2.03 & 1.99 \\
\hline 49 & 4.04 & 3.19 & 2.79 & 2.56 & 2.40 & 2.29 & 2.20 & 2.13 & 2.08 & 2.03 & 1.99 \\
\hline 50 & 4.03 & 3.18 & 2.79 & 2.56 & 2.40 & 2.29 & 2.20 & 2.13 & 2.07 & 2.03 & 1.99 \\
\hline 51 & 4.03 & 3.18 & 2.79 & 2.55 & 2.40 & 2.28 & 2.20 & 2.13 & 2.07 & 2.02 & 1.98 \\
\hline 52 & 4.03 & 3.18 & 2.78 & 2.55 & 2.39 & 2.28 & 2.19 & 2.12 & 2.07 & 2.02 & 1.98 \\
\hline 53 & 4.02 & 3.17 & 2.78 & 2.55 & 2.39 & 2.28 & 2.19 & 2.12 & 2.06 & 2.01 & 1.97 \\
\hline 54 & 4.02 & 3.17 & 2.78 & 2.54 & 2.39 & 2.27 & 2.18 & 2.12 & 2.06 & 2.01 & 1.97 \\
\hline 55 & 4.02 & 3.16 & 2.77 & 2.54 & 2.38 & 2.27 & 2.18 & 2.11 & 2.06 & 2.01 & 1.97 \\
\hline 56 & 4.01 & 3.16 & 2.77 & 2.54 & 2.38 & 2.27 & 2.18 & 2.11 & 2.05 & 2.00 & 1.96 \\
\hline 57 & 4.01 & 3.16 & 2.77 & 2.53 & 2.38 & 2.26 & 2.18 & 2.11 & 2.05 & 2.00 & 1.96 \\
\hline 58 & 4.01 & 3.16 & 2.76 & 2.53 & 2.37 & 2.26 & 2.17 & 2.10 & 2.05 & 2.00 & 1.96 \\
\hline 59 & 4.00 & 3.15 & 2.76 & 2.53 & 2.37 & 2.26 & 2.17 & 2.10 & 2.04 & 2.00 & 1.96 \\
\hline
\end{tabular}
statistic sebagai berikut:

Gambar 22.

F Tabel
Berdasarkan gambar tersebut, maka F tabel dapat dicari di kolom ke satu (1) baris ke 59 yang memiliki nilai 4,00. Jadi, sesuai dengan pengambilan keputusan dapat disimpulkan bahwa nilai uji linearitas adalah signifikan karena $\mathrm{F}$ hitung $<\mathrm{F}$ tabel dimana $F$ hitung=0,883 sedangkan $F$ tabel $=4,00$.

\section{Uji Korelasi Product Moment}

Uji korelasi product moment dilakukan untuk mengetahui ada tidaknya hubungan yang erat antar variabel. Adapun untuk mengetahui ada tidaknya hubungan yang erat antar variabel maka dapat melihat nilai pearson correlation. Nilai korelasi berkisar antara 1 sampai -1, apabila nilai mendekati 1 atau -1 berarti hubungan antara dua variabel semakin kuat. Sebaliknya jika nilai mendekati 0 berarti hubungan antara dua variabel semakin lemah.

Berikut ini adalah tabel uji korelasi product moment:

Tabel 6.

\begin{tabular}{|c|c|c|c|}
\hline \multicolumn{4}{|c|}{ Correlations } \\
\hline \multirow{5}{*}{$\begin{array}{l}\text { Penggunaan } \\
\text { Facebook }\end{array}$} & & $\begin{array}{c}\text { Penggun aan } \\
\text { Facebook }\end{array}$ & $\begin{array}{c}\text { Perilaku } \\
\text { Cyberbullying }\end{array}$ \\
\hline & Pearson & 1 &, $964^{* *}$ \\
\hline & Correlation & & \\
\hline & Sig. (1-tailed) & &, 000 \\
\hline & $\mathrm{N}$ & 61 & 61 \\
\hline \multirow{4}{*}{$\begin{array}{l}\text { Perilaku } \\
\text { Cyberbullying }\end{array}$} & Pearson & $964^{* * *}$ & 1 \\
\hline & Correlation & & \\
\hline & Sig. (1-tailed) & .000 & \\
\hline & $\mathrm{N}$ & 61 & 61 \\
\hline
\end{tabular}

Hasil Uji Korelasi Product Moment

Nilai pada pearson correlation pada tabel tersebut adalah 0,964 dengan koefisien korelasi product moment korelasi signifikan 0,000. Dengan nilai sebesar 0,964 maka mendekati nilai 1. Hal ini menunjukkan adanya keeratan hubungan antara variabel facebook-cyberbullying terhadap variabel 
cyberbullying-facebook.

Jadi, korelasi antara variabel facebook-cyberbullying terhadap variabel cyberbullying-facebook dinyatakan positif dan hubungannya searah.

\section{Pengujian Hipotesis}

Pengujian hipotesis pada penelitian ini adalah untuk melihat apakah hipotesis (Ha) yang diajukan oleh peneliti diterima atau ditolak. Ada dua acuan yang dapat digunakan dalam pengambilan keputusan uji hipotesis. Pertama berdasarkan nilai signifikansi<probabilitas 0,05, maka ada pengaruh variabel penggunaan facebook $(X)$ terhadap variabel perilaku cyberbullying (Y) atau hipotetsis diterima. Adapun sebaliknya jika nilai signifikansi > probablilitas 0,05 , maka tidak ada pengaruh variabel penggunaan facebook $(X)$ terhadap variabel perilaku cyberbullying $(\mathrm{Y})$ atau hipotetsis ditolak.

Pengambilan keputusan uji hipotesis yang kedua adalah dengan menggunakan $t$ hitung dan $\mathrm{t}$ tabel. Jika nilai thitung $>\mathrm{t}$ tabel, maka ada pengaruh variabel penggunaan facebook $(X)$ terhadap variabel perilaku cyberbullying $(\mathrm{Y})$ atau hipotetsis diterima. Apabila $\mathrm{t}$ hitung $<\mathrm{t}$ tabel maka tidak ada pengaruh variabel penggunaan facebook (X) terhadap variabel perilaku cyberbullying (Y) atau hipotetsis ditolak.

Adapun hipotetsis yang diajukan oleh peneliti adalah sebagai berikut:

Ha : Terdapat pengaruh penggunaan facebook terhadap perilaku cyberbullying di kalangan remaja Desa Mantingan.

Uji hipotesis pada penelitian ini menggunakan teknik analisis regresi dengan program IBM SPSS Statistics 25.
Berikut ini adalah tabel hasil uji hipotesis:

Tabel 7.

Uji Hipotesis

\begin{tabular}{|c|c|c|c|c|c|c|}
\hline \multicolumn{7}{|c|}{ Coefficients $^{a}$} \\
\hline & \multirow{2}{*}{ Model } & \multicolumn{2}{|c|}{$\begin{array}{c}\text { Unstandardized } \\
\text { Coefficients }\end{array}$} & \multirow{2}{*}{$\begin{array}{c}\begin{array}{c}\text { Standardized } \\
\text { Coefficients }\end{array} \\
\text { Beta }\end{array}$} & \multirow[b]{2}{*}{$\mathrm{t}$} & \multirow[b]{2}{*}{ Sig. } \\
\hline & & B & $\begin{array}{l}\text { Std. } \\
\text { Error }\end{array}$ & & & \\
\hline \multirow[t]{2}{*}{1} & (Constant) & ,353 & ,933 & & 379 & ,706 \\
\hline & $\begin{array}{l}\text { Penggunaan } \\
\text { Facebook }\end{array}$ & 6,687 & ,025 & 964 & 27,923 & , 000 \\
\hline
\end{tabular}

Berdasarkan tabel tersebut ditemukan nilai siginifikansi (Sig) variabel facebook $(X)$ adalah sebesar 0,000. Karena nilai sig. $0,000<$ probabilitas 0,05 sehingga dapat disimpulkan bahwa Ha diterima. Artinya ada pengaruh penggunaan facebook (Variabel X) terhadap cyberbullying (Variabel $\mathrm{Y})$.

Adapun untuk mencari $\mathrm{t}$ tabel maka dapat menggunakan rumus sebagai berikut:

$$
\mathrm{df}=\mathrm{n}-\mathrm{k}
$$

\section{Keterangan}

$\mathrm{n}$ = sampel.

$\mathrm{k}$ = banyaknya vairabel bebas $(\mathrm{X})$ dan variabel terikat $(\mathrm{Y})$.

Diketahui

$\mathrm{n}=61$

$\mathrm{k}=2$

$\mathrm{df}=61-2=59$

Jadi, nilai df adalah 59 dengan taraf signifikan dalam pengujian uji t $5 \%$ atau 0,025 .

Adapun untuk lebih jelasnya dapat melihat nilai $\mathrm{t}$ table berikut ini:

ISSN : 2085-3521, E-ISSN : 2548-9054 
Titik Persentase Distribusi t $(\mathrm{df}=\mathbf{4 1} \mathbf{- 8 0})$

\begin{tabular}{|c|c|c|c|c|c|}
\hline $\mathrm{Pr}$ & $\begin{array}{l}0.25 \\
0.50\end{array}$ & $\begin{array}{l}0.10 \\
0.20\end{array}$ & $\begin{array}{l}0.05 \\
0.10\end{array}$ & $\begin{array}{l}0.025 \\
0.050\end{array}$ & $\begin{array}{l}0.01 \\
0.02\end{array}$ \\
\hline 41 & 0.68052 & 1.30254 & 1.68288 & 2.01954 & 2.42080 \\
\hline 42 & 0.68038 & 1.30204 & 1.68195 & 2.01808 & 2.41847 \\
\hline 43 & 0.68024 & 1.30155 & 1.68107 & 2.01669 & 2.41625 \\
\hline 44 & 0.68011 & 1.30109 & 1.68023 & 2.01537 & 2.41413 \\
\hline 45 & 0.67998 & 1.30065 & 1.67943 & 2.01410 & 2.41212 \\
\hline 46 & 0.67986 & 1.30023 & 1.67866 & 2.01290 & 2.41019 \\
\hline 47 & 0.67975 & 1.29982 & 1.67793 & 2.01174 & 2.40835 \\
\hline 48 & 0.67964 & 1.29944 & 1.67722 & 2.01063 & 2.40658 \\
\hline 49 & 0.67953 & 1.29907 & 1.67655 & 2.00958 & 2.40489 \\
\hline 50 & 0.67943 & 1.29871 & 1.67591 & 2.00856 & 2.40327 \\
\hline 51 & 0.67933 & 1.29837 & 1.67528 & 2.00758 & 2.40172 \\
\hline 52 & 0.67924 & 1.29805 & 1.67469 & 2.00665 & 2.40022 \\
\hline 53 & 0.67915 & 1.29773 & 1.67412 & 2.00575 & 2.39879 \\
\hline 54 & 0.67906 & 1.29743 & 1.67356 & 2.00488 & 2.39741 \\
\hline 55 & 0.67898 & 1.29713 & 1.67303 & 2.00404 & 2.39608 \\
\hline 56 & 0.67890 & 1.29685 & 1.67252 & 2.00324 & 2.39480 \\
\hline 57 & 0.67882 & 1.29658 & 1.67203 & 2.00247 & 2.39357 \\
\hline 58 & 0.67874 & 1.29632 & 1.67155 & 2.00172 & 2.39238 \\
\hline 59 & 0.67867 & 1.29607 & 1.67109 & 2.00100 & 2.39123 \\
\hline 60 & 0.67860 & 1.29582 & 1.67065 & 2.00030 & 2.39012 \\
\hline 61 & 0.67853 & 1.29558 & 1.67022 & 1.99962 & 2.38905 \\
\hline 62 & 0.67847 & 1.29536 & 1.66980 & 1.99897 & 2.38801 \\
\hline
\end{tabular}

Gambar 23.

T tabel

Berdasarkan tabel $\mathrm{t}$ tersebut, maka $\mathrm{t}$ tabel dapat di cari di kolom 0,025 baris ke-59 yang memilikinilai 2,00100. Adapun thitung dapat dilihat pada bagian penggunaan facebook kolom $\mathrm{t}$ pada tabel uji hipotesis. Nilai dari uji t adalah 27,923. Jadi, sesuai dengan pengambilan keputusan apabila nilai $\mathrm{t}$ hitung $>\mathrm{t}$ tabel di mana 27,923 > 2,00100, maka dapat disimpulkan bahwa ha diterima artinya ada pengaruh penggunaan facebook terhadap perilaku cyberbullying.

Adapun untuk mengetahui berapa persentase dari pengaruh penggunaan facebook terhadap perilaku cyberbullying adalah dengan melakukan uji koefisien determinasi.

Nilai dari uji koefisien determinasi dapat diketahui dengan melihat kolom $\mathrm{R}$ Square pada tabel berikut:
Tabel 8.

Hasil Uji Koefisien Determinasi

\begin{tabular}{|c|c|c|c|c|c|}
\hline \multicolumn{7}{|c|}{ Model Summary $^{\mathrm{b}}$} \\
\hline Model & $\mathrm{R}$ & \multicolumn{2}{|c|}{ R Square } & $\begin{array}{c}\text { Adjusted R } \\
\text { Square }\end{array}$ & $\begin{array}{c}\text { Std. Error } \\
\text { of the } \\
\text { Estimate }\end{array}$ \\
\hline 1 &, $964^{\mathrm{a}}$ &, 930 &, 928 & 1,211 & $\mathrm{t}$ \\
\hline \multicolumn{6}{|l|}{ a. Predictors: (Constant), Penggunaan Facebook } \\
\hline
\end{tabular}

Dari tabel di atas maka dapat dijelaskan bahwa pada kolom $\mathrm{R}$ Square didapatkan nilai sebesar 0,930 atau 93\%. Hal tersebut menunjukkan bahwa facebook memiliki pengaruh terhadap cyberbullying sebesar 93\% sedangkan sedangkan 7\% berasal dari sumbangan variabel-variabel lain yang tidak diteliti pada penelitian ini.

\section{Pembahasan Hasil Penelitian}

Penelitian ini bertujuan untuk melihat adanya pengaruh penggunaan facebook terhadap perilaku cyberbullying di kalangan remaja Desa Mantingan. Hasil uji korelasi menggunakan analisis korelasi product moment dengan 61 sampel remaja menunjukkan perolehan koefisien korelasi 0,964 dengan nilai signifikansi sebesar 0,000. Data analisis tersebut menunjukkan bahwa terdapat pengaruh signifikan dan positif antara penggunaan facebook terhadap perilaku cyberbullying di kalangan remaja Desa Mantingan.

Penggunaan facebook di Indonesia setiap tahun meningkat secara signifikan. Remaja yang masih usia sekolah adalah pengguna facebook paling banyak di Indonesia. Remaja yang bertempat tinggal di Desa Mantingan hampir semua mempunyai akun facebook. Ini menandakan bahwa akun facebook sangat familiar di kalangan remaja Desa Mantingan. 
Penggunaan facebook yang mudah dan murah dinilai penting sebagai sarana komunikasi melalui media sosial. Oleh karena itu, informasi juga bisa diperoleh dengan menggunakan akun facebook.

Adapun faktor yang menyebabkan remaja Desa Mantingan menggunakan facebook adalah untuk mendapatkan informasi dengan cepat dan up to date yang ada di status atau berita. Facebookjuga dapat digunakan selama 24 jam, sehingga dapat digunakan kapanpun untuk mendapatkan informasi.

Selain melakukan komunikasi secara langsung, remaja Desa Mantingan juga berkomunikasi secara tidak langsung dengan menggunakan media sosial facebook. Adapun bentuk komunikasi remaja Desa Mantingan saat menggunakan facebook adalah dengan berkomunikasi melalui pesan (inbox) atau melalui status yang ditulis oleh remaja Desa Mantingan di facebook.

Remaja Desa Mantingan dalam kesehariannya mengisi waktu luang dengan bermain facebook seperti menggunakan fasilitas chat yang ada di facebook atau hanya sekedar melihat status orang lain di beranda.

Adapun bisnis yang dijalankan melalui facebook mulai digemari oleh banyak remaja Desa Mantingan. Facebook digunakan sebagai toko online untuk menawarkan barang dagangan. Sehingga facebook dijadikan sebagai sarana jual-beli online karena mudah dan murah.Tidak hanya menjual barang dagangan, remaja Desa Mantingan juga memanfaatkan facebook untuk membeli produk yang dijual di facebook.
Selain memiliki manfaat yang banyak, facebook juga dapat berakibat buruk apabila disalahgunakan oleh pemakainya. Di era sekarang ini, muncul istilah cyberbullying yaitu suatu tindakan perundungan yang dilakukan melalui media sosial (cyber).

Apabila bullying hanya terjadi ketika korban dan pelaku pembulian bertemu secara langsung maka berberda dengan cyberbullying. Cyberbullying dapat terjadi tanpa perlu melakukan kontak fisik dengan korbannya, cukup melalui media sosial. Hal ini menyebabkan cyberbullying dapat terjadi kapan saja dan di mana saja tanpa terbatas oleh ruang dan waktu.

Faktor yang menyebabkan remaja Desa Mantingan melakukan cyberbullying dapat diketahui dari karakteristik pelaku cyberbullying. Pelaku cyberbullying memiliki kepribadian yang kuat dan memiliki rasa empati yang sedikit kepada orang lain, serta menyukai sensasi dan pengalaman baru. Karakteristik kepribadian tersebut juga ditemukan pada remaja Desa Mantingan.

Selain itu, perilaku cyberbullying dapat ditentukan oleh pengaruh lingkungan seorang remaja. Remaja yang memiliki pengalaman kurang diperhatikan orangtua, tidak harmonis dalam keluarga akan melakukan tindakan agar mendapat perhatian.Salah satunya dengan melakukan tindakan cyberbullying. Faktor ini pula terjadi pada remaja di Desa Mantingan.

Adapun tujuan remaja Desa Mantingan melakukan cyberbullying adalah karena merasa bosan dan tidak ada yang dikerjakan. Adapun untuk menghilangkan kebosanan tersebut, maka remaja berusaha mencari hiburan dengan melakukan tindakan cyberbullying. Selain 
itu, ketakutan pelaku cyberbullying kepada korban juga dapat memicu terjadinya tindakan cyberbullying. Hal ini dikarenakan cyberbullying dilakukan melalui facebook sehingga tidak perlu berhadapan langsung dengan korban.

Menggunakan akun palsu untuk melakukan cyberbullying juga terjadi pada remaja Desa Mantingan. Dengan menggunakan akun facebook palsu maka pelaku merasa aman dan korban sulit untuk melacak identitas pelaku.

Akan tetapi, ada pula remaja Desa Mantingan yang melakukan tindakan cyberbullying tanpa menggunakan akun facebook palsu dan dengan identitas yang jelas. Hal ini terjadi ketika cyberbullying ditujukan kepada temannya sendiri yang sudah dikenal.

Berawal dari saling ejek yang terjadi di dunia nyata. Hal tersebut kemudian berlanjut sampai kepada tindakan membuli yang dilakukan di facebook di mana pelaku mengirimkan kata-kata kasar dan penuh dengan amarah yang bertujuan untuk mengintimidasi dan menyakiti korban baik di status atau lewat pesan (inbox) korban.

Cyberbullying yang terjadi pada remaja Desa Mantingan dapat pula berasal dari komentar negatif di facebook dengan katakata kasar yang diberikan oleh seseorang. Kemudian tindakan tersebut mendapatkan respon balik dan berlanjut menjadi tindakan cyberbullying.

Karakteristik cyberbullying bersifat tidak langsung sehingga pelaku tidak dapat melihat secara langsung reaksi dan respon dari korban. Hal tersebut menyebabkan pelaku cyberbullying tidak memiliki rasa bersalah dan empati pada korban yang dibulinya.

\section{SIMPULAN}

Hasil uji korelasi menggunakan analisis korelasi product moment dengan 61 sampel menunjukkan perolehan koefisien korelasi 0,964 dengan nilai signifikansi sebesar 0,000. Jadi, dapat disimpulkan bahwa terdapat pengaruh signifikan dan positif antara penggunaan facebook terhadap perilaku cyberbullying di kalangan remaja Desa Mantingan. Adapun hipotesis dalam penelitian ini diterima yaitu terdapat pengaruh penggunaan facebook terhadap perilaku cyberbullying di kalangan remaja Desa Mantingan. 


\section{DAFTAR PUSTAKA}

Bungin, Burhan, Metodologi Penelitian Kuantitatif: Komunikasi, Ekonomi, Dan Kebijakan Publik Serta Ilmu-Ilmu Sosial Lainnya, Jakarta: Kencana, 2011, Edisi Ke-2, Cetakan Ke-6.

Hinduja\&Patchin, "Cyberbullying: Identification, Prevention \& Response. Cyberbullying Research Center", www.cyberbullying.us.

Jalil, Abdul, "Cyberbullying",Abduljalil. web.ugm.ac.id/2015/02/12/ cyberbullying.

Pertiwi, Wahyunanda Kusuma, "Riset Ungkap Pola Pemakaian Medsos Orang Indonesia", https: / / tekno.kompas.com / $\mathrm{read} / 2018 / 03 / 01 / 10340027 /$ risetungkap-pola-pemakaian-medsosorang-indonesia.

Smith dkk, Cyberbullying: Its Nature and Impact in Secondary School Pupils, Journal of Child Psychology and Psychiatry, Vol. 49, No. 4, 2008.

Tamburaka, Apriadi, Literasi Media: Cerdas Bermedia Khalayak Media Massa, Jakarta: Rajawali Pers, 2013, edisi pertama, cetakan ke-1. 